\title{
PENYUTRADARAAN NASKAH SULTAN THAHA SAIFUDDIN KARYA EM. YOGISWARA BERBASIS TEATER TRADISI DUL MULUK
}

\author{
Skripsi \\ untuk memenuhi salah satu syarat \\ mencapai derajat Sarjana S-1 \\ Program Studi Teater Jurusan Teater
}

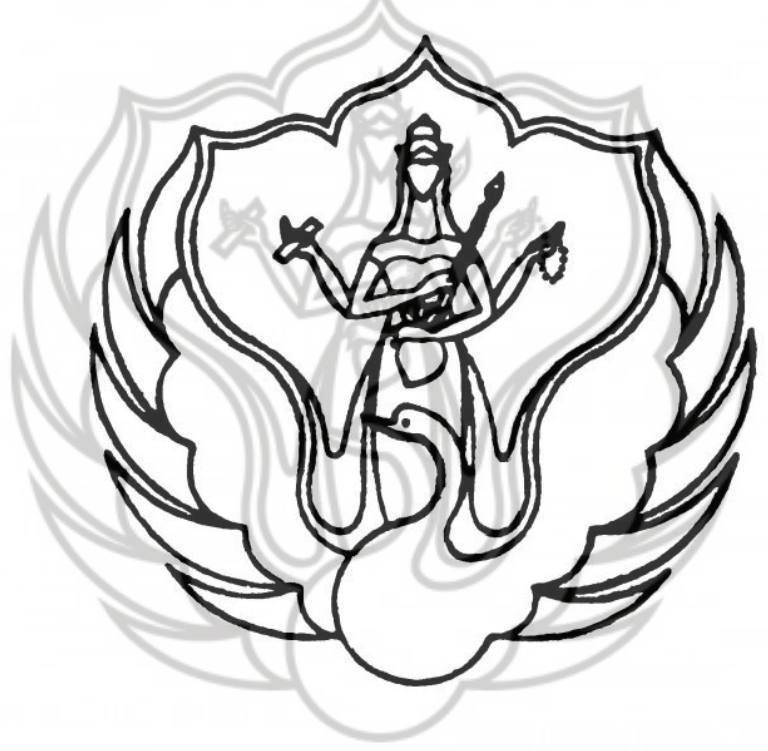

oleh

Medi Saputra

NIM. 1110629014

\section{FAKULTAS SENI PERTUNJUKAN INSTITUT SENI INDONESIA YOGYAKARTA YOGYAKARTA 2016}




\title{
PENYUTRADARAAN NASKAH SULTAN THAHA SAIFUDDIN KARYA EM. YOGISWARA BERBASIS TEATER TRADISI DUL MULUK
}

\author{
Skripsi \\ untuk memenuhi salah satu syarat \\ mencapai derajat Sarjana S-1 \\ Program Studi Teater Jurusan Teater
}

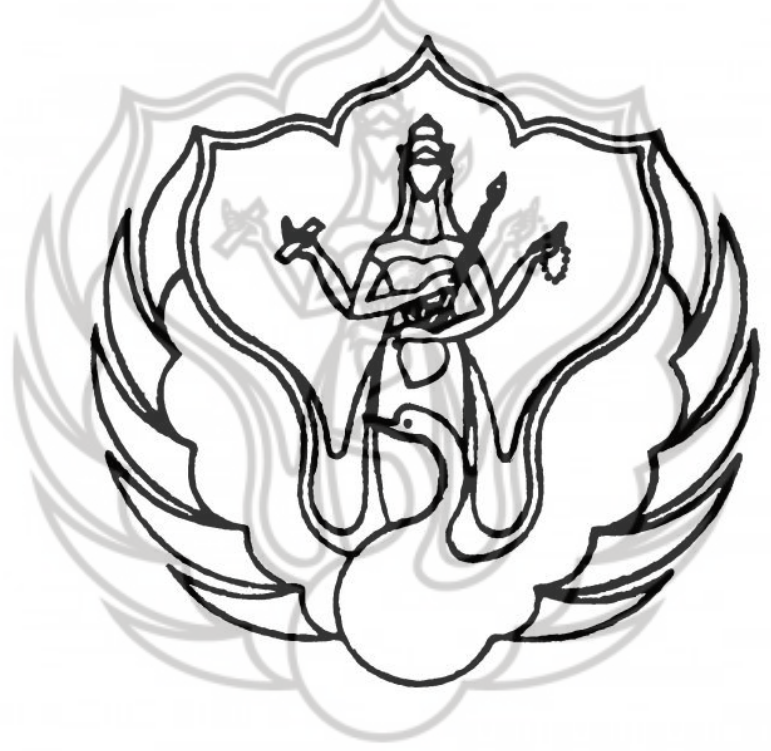

oleh

Medi Saputra

NIM. 1110629014

\section{FAKULTAS SENI PERTUNJUKAN INSTITUT SENI INDONESIA YOGYAKARTA YOGYAKARTA 2016}

UPT Perpustakaan ISI Yogyakarta 


\section{SKRIPSI \\ PENYUTRADARAAN NASKAH SULTAN THAHA SAIFUDDIN KARYA EM. YOGISWARA BERBASIS TEATER TRADISI DUL MULUK}

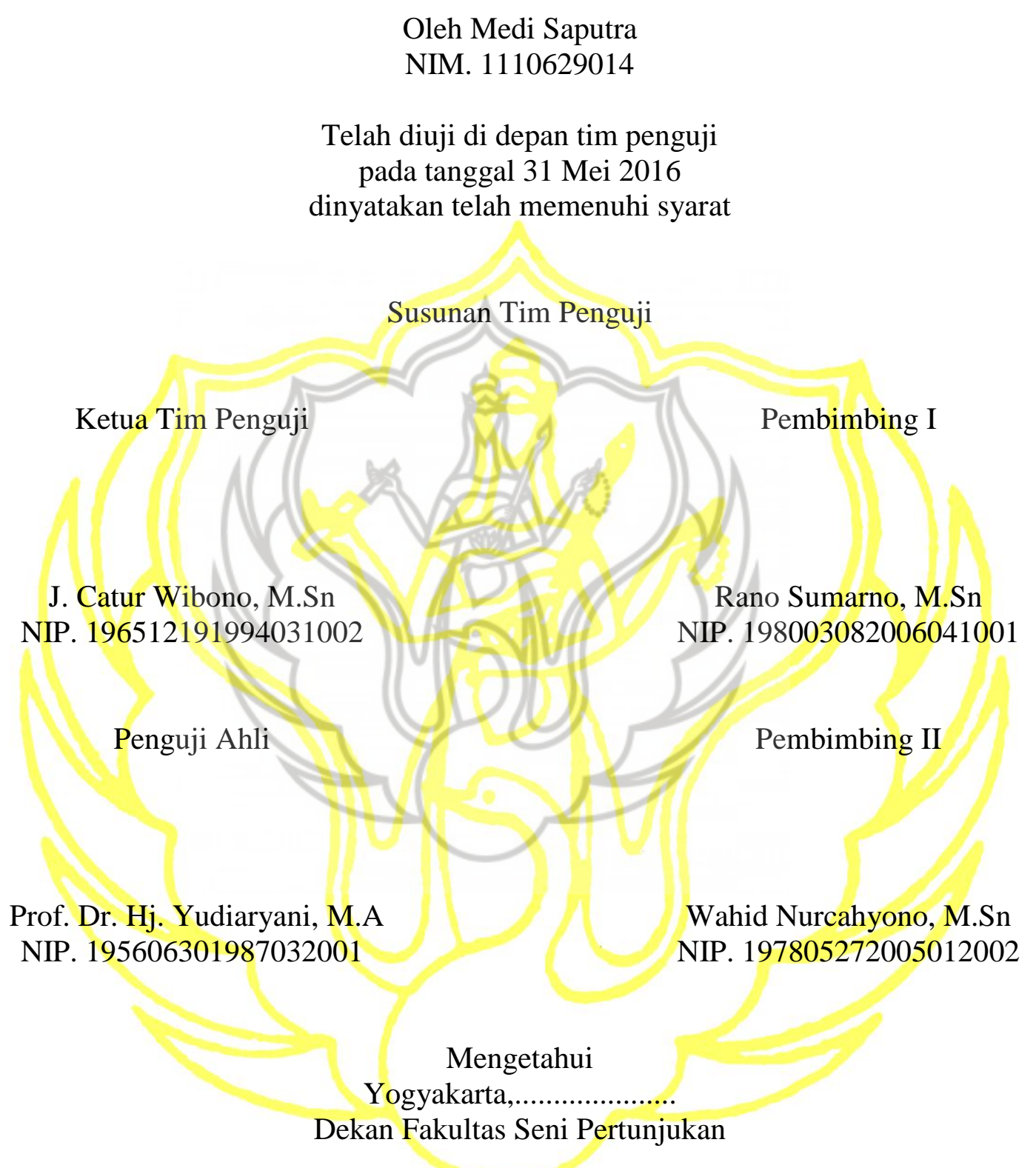

Oleh Medi Saputra

Telah diuji di depan tim penguji

pada tanggal 31 Mei 2016

dinyatakan telah memenuhi syarat

\section{Susunan Tim Penguji}

Ketua Tim Penguji

Rano Sumarno, M.Sn

J. Catur Wibono, M.Sn

NIP. 198003082006041001

Penguji Ahli

NIP. 197805272005012002

Prof. Dr. Hj. Yudiaryani, M.A

NIP. 195606301987032001

\section{UPT Perpustakaan ISI Yogyakarta}




\section{SURAT PERNYATAAN}

Dengan ini saya menyatakan dalam skripsi ini tidak terdapat karya yang pernah diajukan untuk memperoleh gelar sarjana di perguruan tinggi, dan sepanjang pengetahuan saya tidak terdapat karya atau pendapat yang pernah ditulis oleh orang lain kecuali yang secara tertulis diakui dalam skripsi ini dan disebut di kepustakaan. Apabila pernyataan saya ini tidak benar, saya sanggup dicabut hak dan gelar saya sebagai Sarjana Seni dari Program Studi Teater Fakultas Seni Pertunjukan Institut Seni Indonesia (ISI) Yogyakarta.

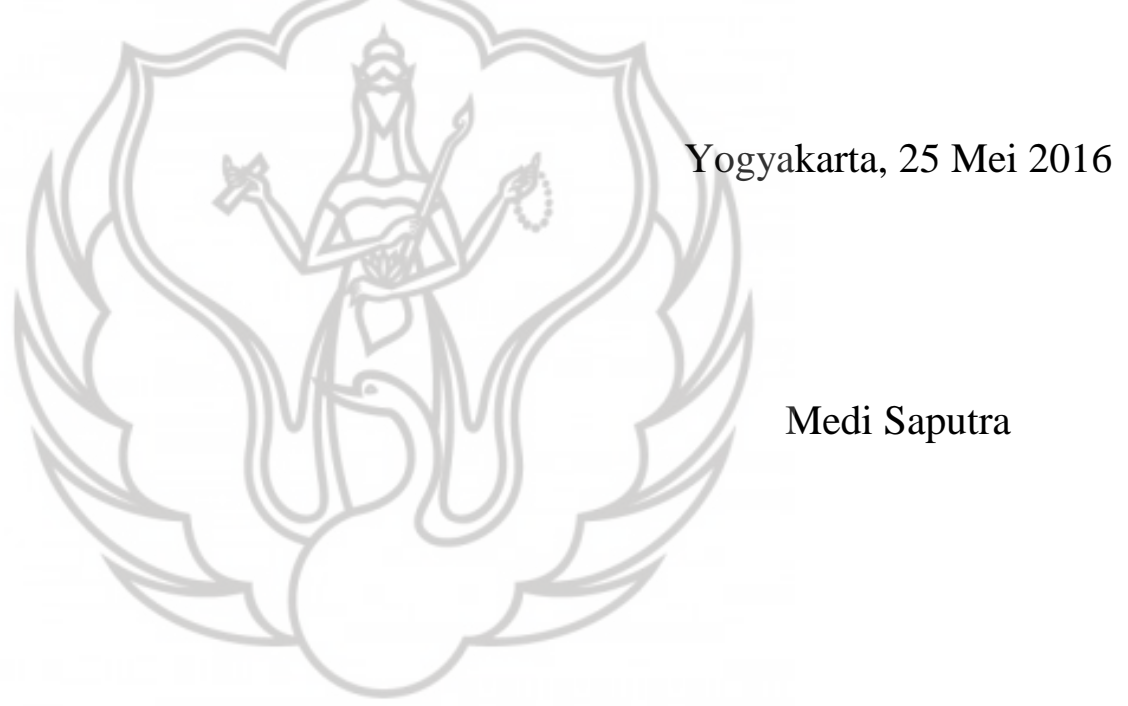

\section{UPT Perpustakaan ISI Yogyakarta}




\section{KATA PENGANTAR}

Puji syukur di panjatkan ke hadirat Allah SWT, atas segala berkat, rahmat, dan karuniaNya, sehingga dapat terselesaikan pertunjukan dan skripsi ini sebagai syarat untuk mencapai derajat sarjana seni. Shalawat beriring salam juga di hadiahkan kepada junjungan Nabi Besar Muhammad SAW yang telah membawa seluruh umat dari gelapnya kehidupan masa lampau menuju dunia yang terang benderang dengan perkembangan zaman, ilmu, dan teknologi yang semakin canggih dan modern.

Karya pertunjukan dan skripsi ini tidak akan bisa terselesaikan tanpa arahan dan bantuan dari pihak yang telah membantu, khususnya untuk kedua orang tua, kakak, dan seluruh keluarga besar A. Djalil Kiten yang tak hentinya memberikan dukungan serta semangat. Untuk itu diucapkan banyak terimakasih kepada Rano Sumarno, M.Sn dan Wahid Nurcahyono, M.Sn, selaku pembimbing I dan II yang bersedia meluangkan waktu untuk mendampingi seluruh rangkaian proses dari tahap pengolahan ide, sampai kepada pertunjukan ini digelar. Terima kasih juga diucapkan kepada Ketua Jurusan Joanes Catur Wibono. M.Sn, Sekretaris Jurusan Drs. Sumpeno. M.Sn, selaku tim penguji di Jurusan Teater ISI Yogyakarta dan kepada Prof. Dr. Hj. Yudiaryani, M.A sebagai penguji ahli.

Disampaikan pula rasa terima kasih kepada semua pihak yang membantu selama penulis menempuh pendidikan di ISI Yogyakarta. Kepada seluruh dosen Jurusan Teater ISI Yogyakarta yang telah mengayomi dan memberikan limpahan ilmu selama menempuh pendidikan, para staf dan karyawan yang terus membantu

\section{UPT Perpustakaan ISI Yogyakarta}


dalam memberikan pelayanan dan fasilitas terbaik. Serta kawan-kawan tercinta yang telah membantu berlangsungnya pertunjukan tugas akhir ini.

Karya ini adalah sebuah persembahan untuk Sanggar Seni Kerlip SMA Negeri 1 Kota Jambi yang menjadi awal mula mengenal dunia perteateran dan untuk daerah kelahiran kebanggaan, Jambi. Ambisi yang sejak awal ingin menyampaikan suatu hal melalui pertunjukan teater, akhirnya dapat terwujud dengan memperkenalkan sosok pejuang Jambi di tanah Jawa. Proses perjuangan yang tidak mudah untuk menyelesaikan skripsi dan menyuguhkan pertunjukan ini tentu berkat dukungan dari kedua orang tua dan orang-orang tercinta. Begitu banyak ucapan terima kasih yang mestinya terlontar dengan harapan dapat memuaskan segala mata yang memandang dari sebuah pertunjukan teater sederhana. Akhirnya, dengan segala keterbatasan pada tulisan ini semoga bermanfaat bagi para pembaca.

Yogyakarta, 25 Mei 2016

Medi Saputra

\section{UPT Perpustakaan ISI Yogyakarta}




\section{DAFTAR ISI}

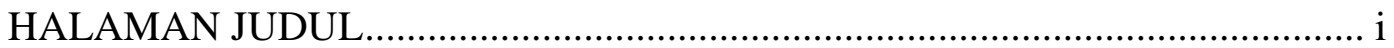

HALAMAN PENGESAHAN .......................................................................... ii

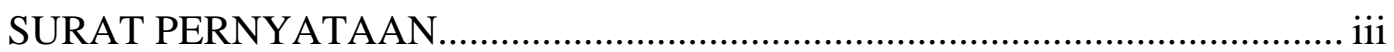

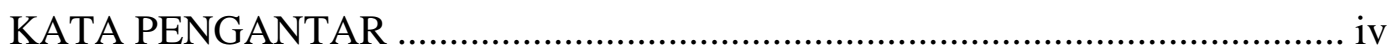

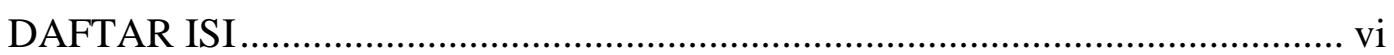

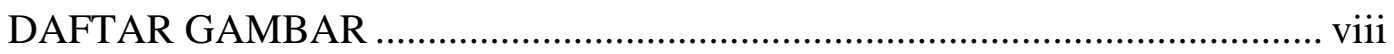

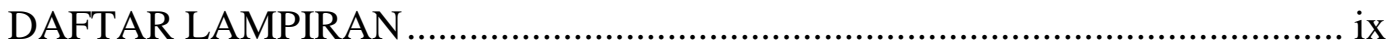

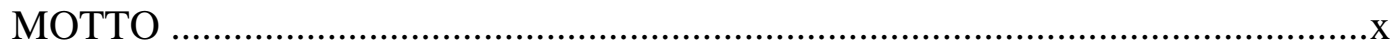

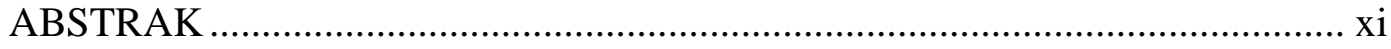

BAB I PENDAHULUAN

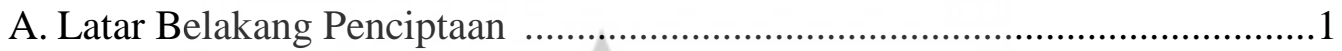

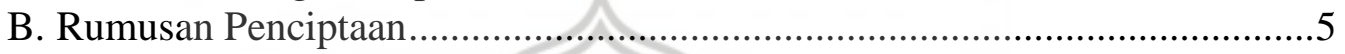

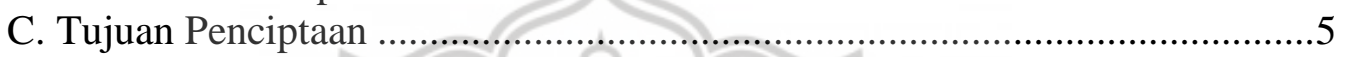

D. Tinjauan Karya dan Tinjauan Pustaka ........................................................6

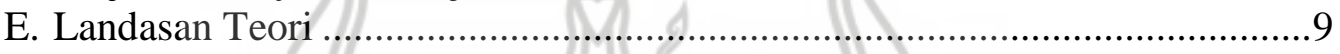

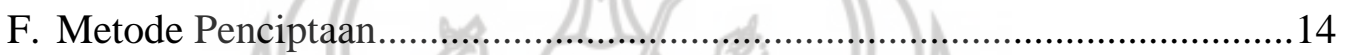

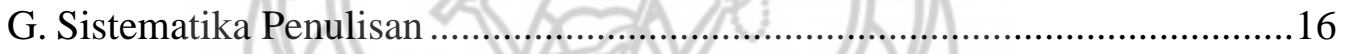

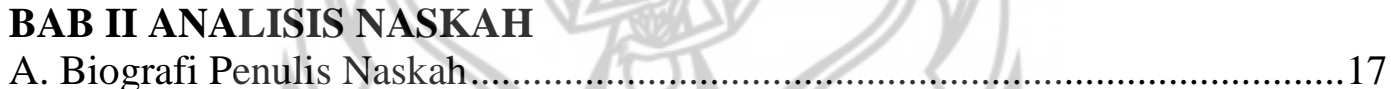

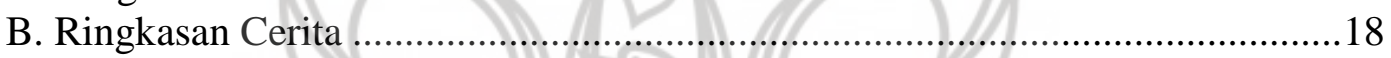

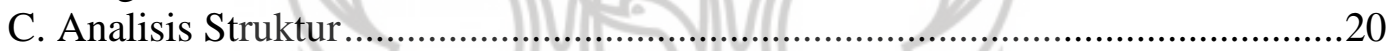

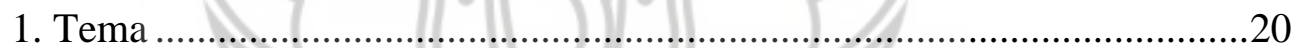

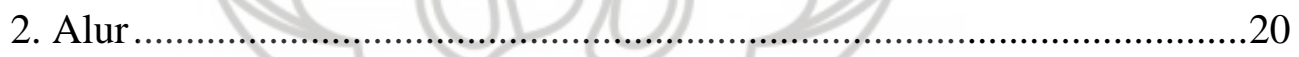

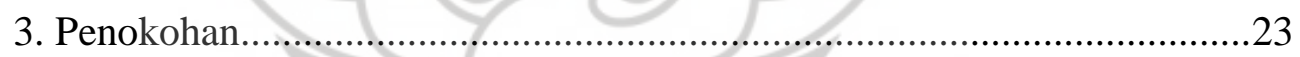

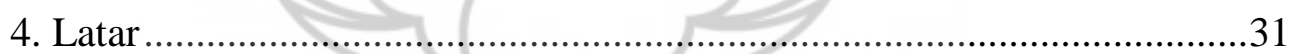

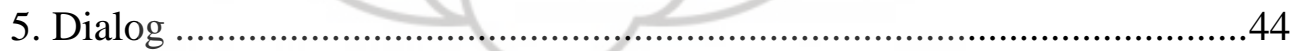

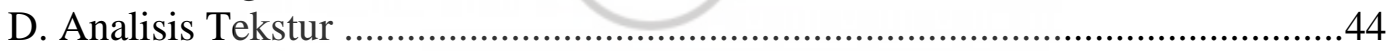

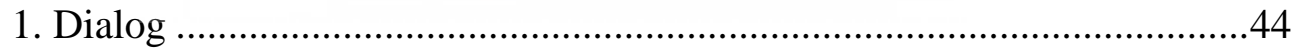

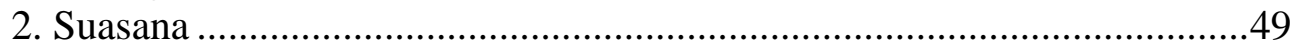

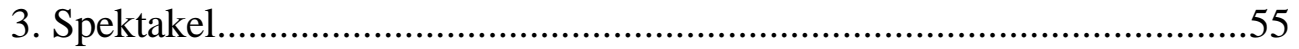

BAB III PENYUTRADARAAN

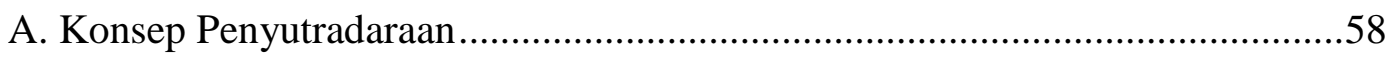

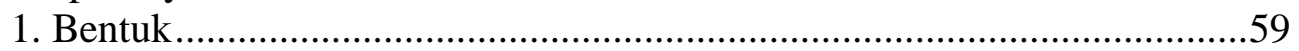

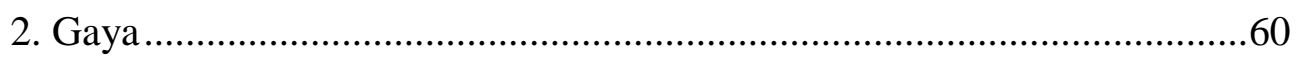

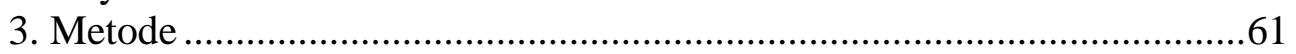

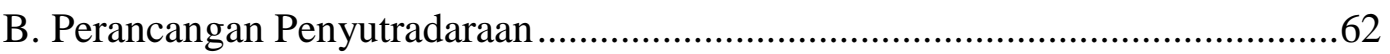

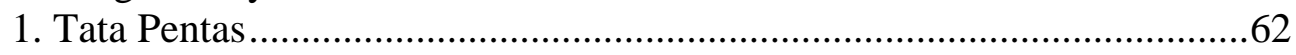

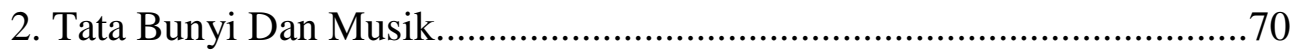

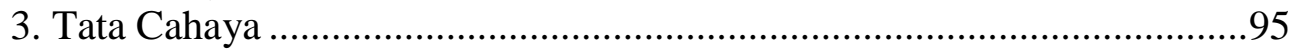

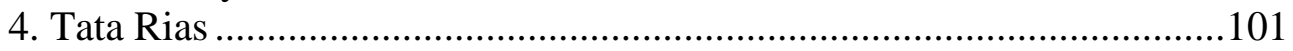

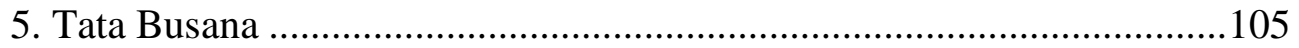




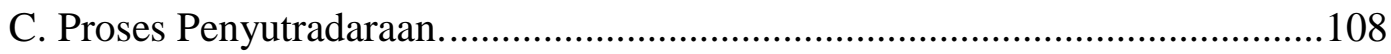

1. Memilih pemain dan pekerja artistik .................................................108

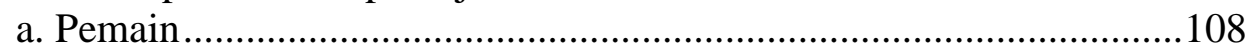

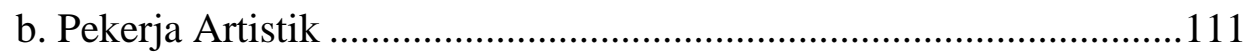

2. Bekerja sama dengan staf artistik dan non artistik ................................112

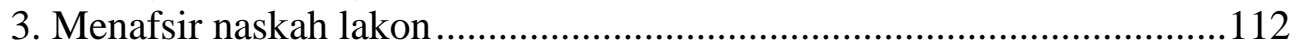

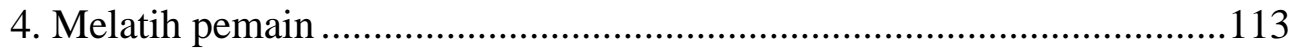

a. Latihan Ketrampilan khusus .........................................................113

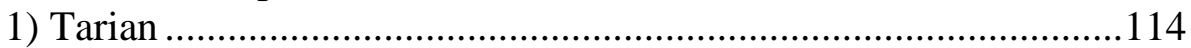

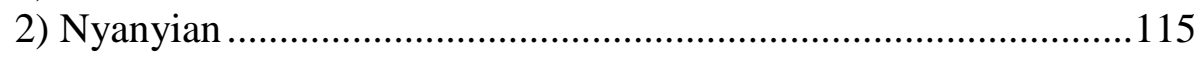

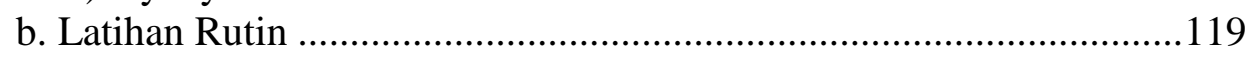

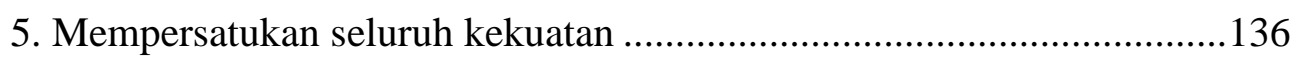

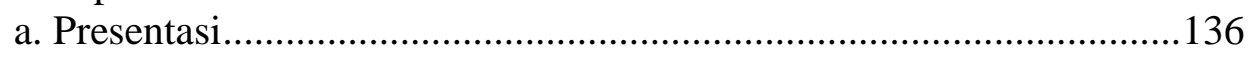

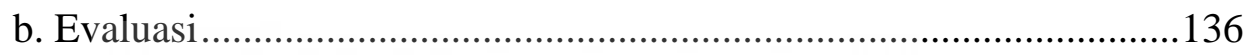

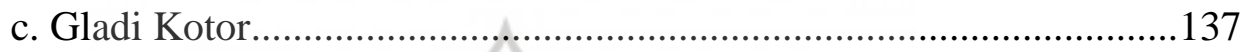

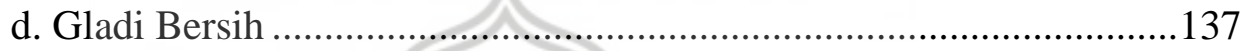

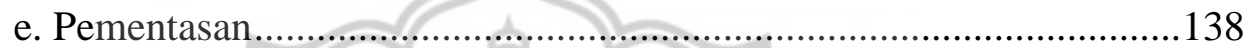

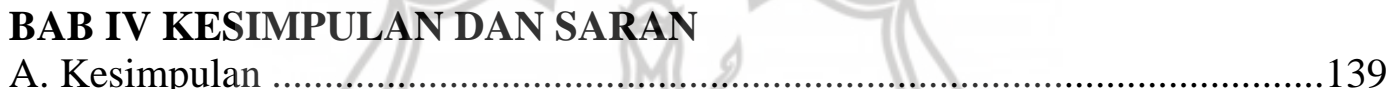

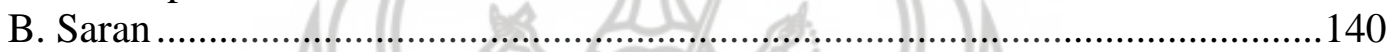

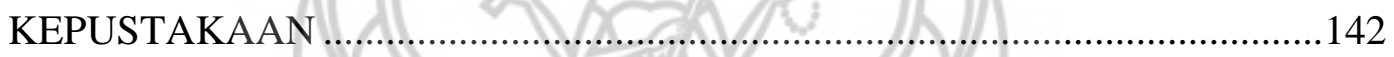

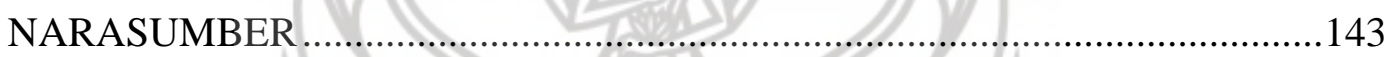

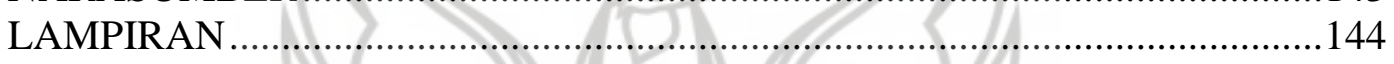

\section{UPT Perpustakaan ISI Yogyakarta}




\section{DAFTAR GAMBAR}

Gambar 1. Set panggung permanen .63

Gambar 2. Set panggung adegan kerajaan Sultan Thaha .................................63

Gambar 3. Set panggung adegan markas Belanda...........................................64

Gambar 4. Set panggung adegan peperangan hutan betung berdarah ................65

Gambar 5. Perubahan set panggun tetap......................................................66

Gambar 6. Perubahan set panggung kerajaan Sultan Thaha..............................66

Gambar 7. Perubahan set panggung markas Belanda....................................67

Gambar 8. Perubahan set panggung adegan hutan betung berdarah .................67

Gambar 9. Senjata tradisional Jambi .............................................................68

Gambar 6. Senjata modern Jambi .....................................................................69

Gambar 11. Replika properti senjata ...........................................................69

Gambar 12. Plot lampu pertunjukkan Sultan Thaha Saifuddin .........................96

Gambar 13. Sketsa jatuh lampu pertunjukkan Sultan Thaha Saifuddin adegan pembuka / Grand Opening ......................................................97

Gambar 14. Sketsa jatuh lampu pertunjukkan Sultan Thaha Saifuddin adegan Kesultanan Jambi ................................................................ 98

Gambar 15. Sketsa jatuh lampu pertunjukkan Sultan Thaha Saifuddin adegan markas Belanda.

Gambar 16. Sketsa jatuh lampu pertunjukkan Sultan Thaha Saifuddin adegan

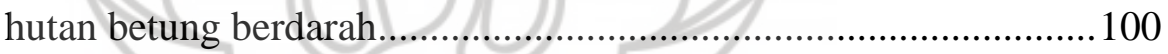

Gambar 17. Rancangan rias Sultan Thaha kecil, remaja, dewasa .....................101

Gambar 18. Rancangan rias para masyarakat perempuan ................................102

Gambar 19. Rancangan rias Sultan Muhammad Fachruddin, muda dan tua......102

Gambar 20. Rancangan rias Kolonel GW Beeger .............................................103

Gambar 21. Rancangan rias Mayor Van Langen..............................................103

Gambar 22. Rancangan rias Narator / Residen............................................... 104

Gambar 23. Rancangan rias Prajurit Belanda...................................................104

Gambar 24. Rancangan rias Pasukan Fisabilillah...............................................105

Gambar 25. Busana Sultan Thaha kecil dan dewasa ..........................................106

Gambar 26. Busana Pasukan Fisabilillah dan Prajurit Belanda .........................106

Gambar 27. Busana Petinggi-petinggi Belanda...............................................107

Gambar 28. Busana para petinggi Belanda...................................................107

Gambar 29. Busana para wanita sebagai penari dan masyarakat Jambi.............108

Gambar 30. Latihan menari Zapin Melayu Jambi ...........................................114

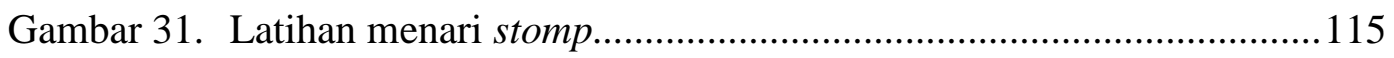




\section{DAFTAR LAMPIRAN}

Lampiran 1. Naskah drama Sultan Thaha Saifuddin karya EM. Yogiswara 144

Lampiran 2. Jadwal proses pertunjukkan Sultan Thaha Saifuddin 160

Lampiran 3. Poster 161

Lampiran 4. Tiket dan selebaran (flyer) 162

Lampiran 5. Cover Proposal Kerjasama dan Donatur 163

Lampiran 6. Dokumentasi Foto Pertunjukan 164

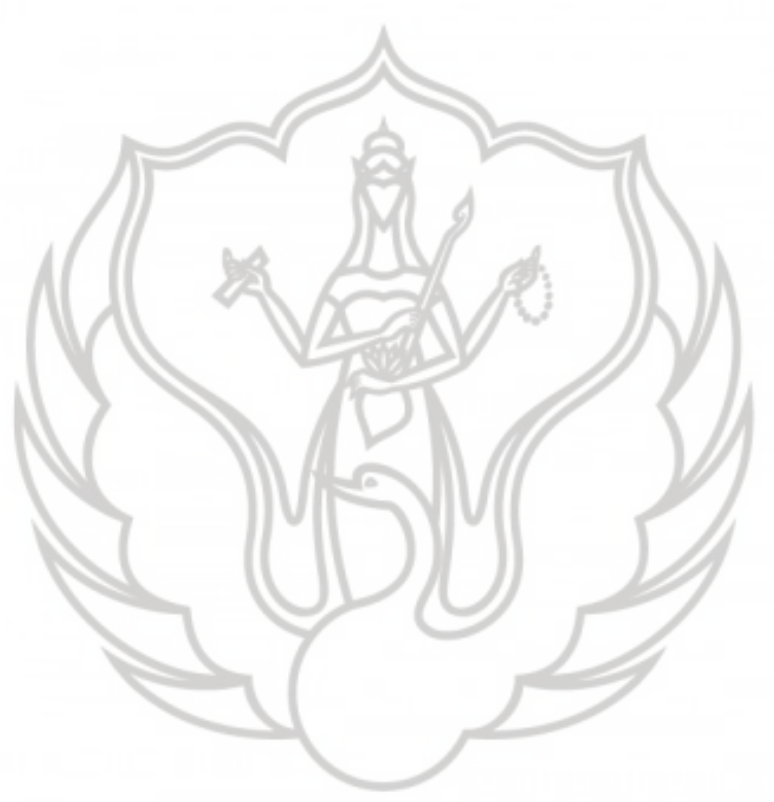

\section{UPT Perpustakaan ISI Yogyakarta}


MOTTO

“JIWA MELAYU TAK KAN HILANG DI RANTAU, KARENA SENI BERJUTA KILAU”

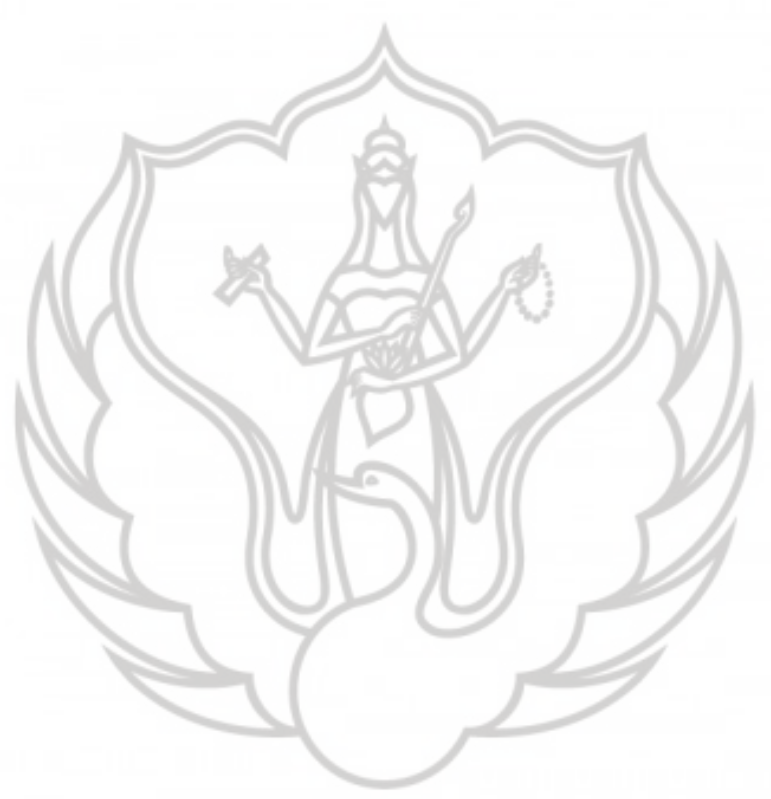

\section{UPT Perpustakaan ISI Yogyakarta}




\begin{abstract}
ABSTRAK
Mengangkat sebuah cerita perjuangan rakyat ke dalam bentuk teater tentulah bertolak belakang dengan konsumsi publik saat ini. Masyarakat yang dominan memilih menonton film atau acara-acara televisi membuat seni teater menjadi terbelakang. Hal ini disebabkan oleh pengaruh globalisasi dan perkembangan teknologi yang tiap hari semakin canggih. Kemudian muncullah ide kreatif sebagai sutradara, yang memiliki tanggung jawab dalam mengemas pertunjukkan untuk kembali mengangkat nilai-nilai tradisi yang saat ini tertinggal. Dul Muluk, salah satu bentuk teater tradisi yang kemudian dijadikan basis dalam penyutradaraan pertunjukan teater dengan naskah Sultan Thaha Saifuddin karya EM. Yogiswara.

Sultan Thaha Saifuddin adalah sosok pejuang dari Negeri Jambi dan merupakan raja terakhir dari Kesultanan Tanah Pilih Kampung Gedang Jambi. Sikap heroik, tegas, dan bijaksananya membuat masyarakat Jambi mendukung penuh keteguhan hati Sultan Thaha untuk melawan penjajah Belanda. Untuk mengangkat kembali cerita perjuangan rakyat ini, maka dikumpulkan data-data sebagai acuan dari karya-karya terdahulu mengenai teater tradisi Dul Muluk dan perkembangannya, serta cerita-cerita penguat mengenai sejarah Kesultanan Melayu Jambi. Data yang diperoleh kemudian diaplikasikan untuk menggarap sebuah bentuk teater modern yang sekiranya dapat diterima oleh masyarakat saat ini.
\end{abstract}

Kata Kunci : Perjuangan Rakyat, Sultan Thaha, Dul Muluk, Sutradara, Teater.

\title{
ABSTRACT
}

Adapting a legendary folklore into the role play is absolutely very contradiction with public watcher nowdays. Society dominantly has chosen to watch movies or another television programs that makes theatre's becoming retarded. It caused of globalization effect and technology development which more sophisticated day by day. Afterwards, a creative idea as a play director was turning up that has a responsibility for making a play to readapt norms and moral values which had been left behind. Dul Muluk, as one of traditional role plays that had been a basic play director processing in a theatre with the title Sultan Thaha Saifuddin from EM. Yogiswara.

Sultan Thaha Saifuddin is a heroic person from Negeri Jambi and the last king from Kesultanan Tanah Pilih Kampung Gedang Jambi. His heroic, firm and wise makes Jambi society support him consistently and solidly to avoid the Netherland. In adapting this legendary folklore, the writer was collecting the data as references from earlier works about Dul Muluk theatre and its development, also the supporting stories about the legend of Kesultanan Melayu Jambi. The data was found and involved for making a modern theatre that can be accepted by the society nowdays.

Keywords: People Struggling, Sultan Thaha, Dul Muluk, Play Director, Theatre 


\section{BAB I}

\section{PENDAHULUAN}

\section{A. Latar Belakang Penciptaan}

Dunia film Indonesia belakangan ini disuguhi cerita yang mengangkat sosok tokoh pejuang bangsa. "Sang Pencerah" (2010), "Soegija” (2012), “Soekarno" (2013), “Guru Bangsa: Tjokroaminoto” (2015), “Jenderal Soedirman" (akan dirilis Agustus 2016) adalah film-film yang muncul dengan mengusung tema sejarah Bangsa Indonesia dan mampu mencuri perhatian masyarakat Indonesia saat ini. Tokoh-tokoh yang diceritakan melalui layar lebar tersebut berlatar belakang Jawa. Banyak tokoh di daerah luar Jawa yang tidak memiliki media ungkap yang sepadan.

Pulau Sumatera yang identik dengan budaya melayu memiliki banyak sosok pejuang bangsa. Sebagai remaja melayu muncul semangat ingin tahu mengenai tokoh pejuang di daerah sendiri, Jambi. Banyak tokoh yang sering diceritakan, akan tetapi lebih banyak pula yang terlupakan. Salah satunya tokoh Sultan Thaha Saifuddin yang merupakan raja terakhir di Kerajaan Jambi, kini hanya dikenal kalangan remaja sebagai nama bandar udara (bandara) di Provinsi Jambi.

Pengenalan cerita rakyat, cerita tutur, mitos, dan sejarah dapat disalurkan melalui berbagai macam media ungkap salah satunya adalah teater. Yudiaryani (2002: 8) dalam buku Panggung Teater Dunia menjelaskan bahwa teater merupakan kerja seni yang paling obyektif, karena secara karakteristik teater

\section{UPT Perpustakaan ISI Yogyakarta}


menghadirkan sekaligus baik pengalaman luar maupun dalam hidup manusia melalui kemampuan akting seorang pemain. Teater merupakan pula kerja seni yang cukup kompleks. Hal ini disebabkan teater menuntut kehadiran beberapa seniman: aktor, penulis naskah, sutradara, pemusik, pelukis, penata lampu, koreografer, dan sebagainya, untuk menggabungkan kreativitasnya.

Teater Art in Revolt (AiR) Jambi, komunitas pegiat teater di Jambi ikut meyampaikan kisah-kisah sejarah perjuangan Jambi melalui media teater. Di tahun 2013, komunitas yang didominasi oleh mahasiswa tersebut mementaskan sebuah cerita yang berjudul "Sultan Thaha Saifuddin", ditulis dan disutradarai langsung oleh sang pimpinan EM. Yogiswara. Melihat antusias masyarakat Jambi dalam mengapresiasi pertunjukan tersebut, EM. Yogiswara kembali menginisiasi untuk mementaskan pertunjukan teater berjudul "Raden Mattaher" di tahun berikutnya. Kedua naskah bertajuk Hero of Jambi yang berawal dari proses kreatif tersebut, lalu dibakukan menjadi sebuah buku dengan judul PANCANG NEGERI (dua drama sejarah jambi) di tahun 2014.

Berawal dari membaca buku tersebut muncul keinginan untuk menciptakan sebuah proses kreatif dan bertindak menjadi sutradara. Seorang sutradara mempunyai tanggung jawab yang menyeluruh dalam suatu pertunjukan drama, terutama tanggung jawab terhadap: naskah drama, pelaku (aktor), penata panggung (manajer panggung), penonton (Prasmadji, 2008: 19). Tanggung jawab yang harus diselesaikan pertama kali oleh sutradara adalah pemilihan naskah. Pemilihan naskah terhambat oleh dua pilihan naskah 
tersebut. Sempat terjadi perdebatan langsung bersama penulis naskah. EM. Yogiswara (28 September 2015) menjelaskan,

"pada naskah Sultan Thaha saya hanya ingin menyampaikan pesan pengkhianatan yang terjadi saat perjuangan rakyat Jambi berlangsung. Naskah Raden Mattaher jauh lebih kompleks dan masih lebih banyak yang tidak mengenal perjuangan beliau. Untuk di Yogya lebih baik mementaskan naskah Sultan Thaha, karena lebih umum diketahui orang."

Maka dipilihlah naskah berjudul Sultan Thaha Saifuddin yang dijadikan modal awal untuk berproses kreatif dalam penciptaan penyutradaraan dengan beberapa pertimbangan: Pertama, Sultan Thaha Saifuddin adalah pahlawan nasional Jambi yang telah disahkan pada tanggal 24 Oktober 1977. (sumber: Yayasan Kesultanan Jambi Darul Haq). Kedua, Sultan Thaha Saifuddin adalah Raja terakhir dari Kesultanan Jambi, mampu dengan tegas menolak segala perjanjian dengan Belanda yang merugikan rakyat Jambi. Ketiga, pesan yang disampaikan melalui teks oleh penulis naskah jauh lebih tajam dari pada naskah-naskah tentang pejuang Jambi lainnya yakni pengkhianatan. Keempat, adanya sumber penguat dari Yayasan/Kesultanan Jambi Darul Haq dibawah pimpinan Bapak Sabarudin Achmad yang menjelaskan lebih detail mengenai perjuangan Sultan Thaha Saifuddin.

Kerja penyutradaraan naskah Sultan Thaha Saifuddin adalah tanggung jawab sutradara terhadap penulis naskah, pelaku, penata panggung, dan terutama penonton. Sutradara harus mampu membuat satu paham terhadap konsep dan gagasan yang akan dimunculkan pada pertunjukan. Teater AiR Jambi di tahun 2013 mementaskan naskah Sultan Thaha Saifuddin dengan gaya realisme. Pertunjukan ini diuntungkan dengan para pelaku yang berdarah 
melayu lalu disuguhkan kepada masyarakat melayu. Penciptaan penyutradaraan naskah Sultan Thaha Saifuddin nantinya akan dihadapkan pada sumber daya manusia yang global, dan penonton yang didominasi penduduk Jawa. Mengangkat cerita perjuangan rakyat Jambi di tanah Jawa tentu memerlukan ide atau gagasan yang matang dalam pengemasan pertunjukan. Tantangan terbesar adalah mengenalkan sosok pejuang Jambi ke masyarakat luas yang kekinian. Tentu ketertarikan masyarakat saat ini tidak lagi sama dengan zaman dulu untuk mengapresiasi sebuah pertunjukan teater. Untuk itu pertunjukan akan dikemas ke dalam bentuk pertunjukan teater modern dengan berbasis teater tradisi Dul Muluk.

Dul Muluk sampai saat ini merupakan salah satu teater tradisi yang dikenal di Jambi. Tetapi Dewojati (2012: 94), A. Kasim Achmad (2006: 125) menuliskan Teater Dul Muluk berasal dari Sumatera Selatan. Salah satu versi menyebutkan bahwa teater ini berasal dari syair Raja Ali Haji, sastrawan yang pernah bermukim di Riau. Bentuk pertunjukan Dul Muluk tidak berbeda sebagai teater rakyat umumnya. Bentuk pertunjukan menggunakan campuran media ungkap terdiri dari tari, nyanyi, laku, dengan menggunakan dialog yang sering dinyanyikan. Karena ungkapan dialog yang berbentuk pantun, maka cara mengungkapkan yang paling tepat adalah dinyanyikan. Unsur musik merupakan bagian yang tak terpisahkan dari lakon yang dipertunjukkan. (Achmad, 2006: 126). Bonarti Lubis, salah satu praktisi teater tradisi Dul Muluk Jambi menyampaikan dalam diskusi persiapan Festival Nasional Teater Remaja di bulan April 2016 lalu bahwa Dul Muluk Jambi memiliki 
karakteristik lucu, melucu, atau sering disebut komedi. Seiring perkembangannya di Jambi, teater tradisi Dul Muluk semakin berkembang bebas dan leluasa mengikuti perkembangan zaman dan trend yang sedang marak dikalangan masyarakat.

Proses penciptaan pertunjukan teater Sultan Thaha Saifuddin karya EM. Yogiswara berbasis teater tradisi Dul Muluk ini diharapkan dapat menjadi sumber pengetahuan dan seni yang baru. Mengembalikan memori para kalangan remaja tentang tokoh-tokoh terdahulu dalam memperjuangkan kebebasan diri dan negeri dari penjajah. Terlebih dapat mengenalkan sejarah melalui seni kepada generasi muda baik yang melayu maupun non-melayu yang banyak terpengaruh efek globalisasi.

\section{B. Rumusan Penciptaan}

Berdasarkan uraian pada latar belakang penciptaan tersebut, muncul rumusan penciptaan, yaitu: bagaimana menciptakan pertunjukan teater berdasarkan naskah Sultan Thaha Saifuddin karya EM. Yogiswara berbasis teater tradisi Dul Muluk?

\section{Tujuan Penciptaan}

Merujuk dari rumusan penciptaan di atas, maka diharapkan tercapainya tujuan, yaitu: mampu menciptakan pertunjukan teater berdasarkan naskah Sultan Thaha Saifuddin karya EM. Yogiswara berbasis teater tradisi Dul Muluk.

\section{UPT Perpustakaan ISI Yogyakarta}




\section{Tinjauan Karya dan Tinjauan Pustaka}

Tinjauan karya dibutuhkan untuk terus menciptakan kebaruan dari pertunjukan yang pernah dipentaskan sebelumnya. Sehingga pada prosesnya mampu meningkatkan kreativitas dalam menciptakan sebuah karya baru yang original. Istilah kreativitas bersumber dari bahasa inggris yaitu "to create" yang dapat diterjemahkan ke dalam Bahasa Indonesia dengan istilah "mencipta" yang berarti menciptakan atau membuat sesuatu yang berbeda (bentuk, susunan, atau gayanya) dengan yang lazim dikenal orang banyak. (Damajanti, 2006: 21).

Karya terdahulu yang menjadi bahan perbandingan dalam penyutradaraan naskah Sultan Thaha Saifuddin karya EM. Yogiswara adalah 2 pertunjukan bertajuk Hero Of Jambi:

1. Pementasan SULTAN THAHA SAIFUDDIN oleh Teater Art in Revolt (AiR) Jambi tahun 2013, di Taman Budaya Jambi.

2. Pementasan RADEN MATTAHER oleh Teater Art in Revolt (AiR) Jambi tahun 2014, di Taman Budaya Jambi.

Kedua pementasan yang ditulis dan disutradarai langsung oleh EM. Yogiswara tersebut dikemas dengan menggunakan pola akting realisme. Dipentaskan di dalam gedung teater arena dengan bentuk menyerupai tapal kuda. Penonton berada mengelilingi panggung seperti setengah lingkaran. Bentuk panggung arena membuat penataan panggung tidak mengikuti pola realisme. Pembagian ruang dan waktu dibantu dengan penataan cahaya. Penggunaan kostum seadanya hanya untuk menjelaskan tokoh yang dimainkan

\section{UPT Perpustakaan ISI Yogyakarta}


seperti, Belanda menggunakan kostum tentara dan baret, pejuang Jambi menggunakan baju koko, celana dasar, sarung, sorban atau kopiah, dan celana dasar.

Karya Sultan Thaha Saifuddin kali ini diciptakan berbeda dari kedua karya tersebut. Pertunjukan teater Sultan Thaha Saifuddin akan menonjolkan musik, tari, dan lagu yang kental dengan nuansa melayu sebagai basis dari teater tradisi Dul Muluk. Menonjolkan basis ini dimaksudkan untuk mengembangkan konsep teater tradisi sehingga terjadi kebaruan dan sesuai dengan perkembangan zaman. Kemudian memudahkan untuk memadukan bentuk-bentuk audio dan visual modern seperti acrobatic, acapella, hip hop, stombpin sebagai bentuk pengaruh globalisasi yang terjadi terhadap seni, budaya, sejarah, dan kebaruan untuk sebuah pertunjukan teater.

Pada proses penggarapannya banyak sumber-sumber yang mampu mengembangkan gagasan-gagasan penciptaan. Film Pitch Perfect 2, menjadi inspirasi dalam pengemasan adegan pembukaan dengan cara menyanyi secara vocal group. Film Any Body Can Dance (ABCD), mematangkan konsep garapan adegan pembukaan untuk tidak hanya menyanyi tetapi juga menari.

Kemudian penyutradaraan naskah Sultan Thaha Saifuddin karya EM. Yogiswara diperkaya melalui cerita lisan dari Yayasan Kesultanan Darul Haq Jambi di bawah pimpinan Bapak Sabarudin Achmad. Cerita secara langsung yang bersifat wawancara ini akan menjadi modal untuk memperkuat dan mengembangkan gagasan saat proses penciptaan. 
Tinjauan pustaka yang diacu dalam penyutradaraan naskah Sultan Thaha Saifuddin karya EM. Yogiswara ini menggunakan referensi sebagai berikut:

Dra. Yudiaryani, M.A. Panggung Teater Dunia (Perkembangan dan Perubahan Konvensi). Tugas seorang sutradara berada pada tahapan sebagai berikut, pertama, sutradara menterjemahkan naskah untuk menentukan gaya panggung sebagai konsep dasar produksi. Gaya ini kemudian berguna untuk membentuk panggung. Kedua, sutradara memilih dan melatih pemain. Ketiga, sutradara menjalin kerja sama dengan penata artistik. Keempat, sutradara menyatukan seluruh elemen kerja hingga akhir produksi (Yudiaryani, 2002:344). Kutipan ini menjadi pedoman sutradara untuk melakukan kerja penyutradaraan.

Lalu EM. Yogiswara dalam tulisannya pada buku PANCANG NEGERI (dua drama sejarah jambi). Buku ini membantu sutradara dalam menafsirkan naskah berdasarkan tulisan yang ada di dalamnya. Serta satu cerita lainnya mampu memperjelas keutuhan maksud naskah sebab memiliki kesenimambungan yang sangat erat. Raden Mattaher yang menjadi penerus perjuangan Sultan Thaha mampu menggambarkan bagaimana perjuangan pada saat sebelumnya.

Kemudian A. Kasim Achmad menjelaskan secara menyeluruh dalam bukunya Mengenal Teater Tradisional di Indonesia tentang Dul muluk yang dijelaskan sebagai salah satu bentuk teater tradisi di Sumatera. Bentuk dan gaya Dul Muluk pada pembahasannya menjadi acuan sutradara dalam menggarap pertunjukan Sultan Thaha Saifuddin. Ditambah penjelasan

\section{UPT Perpustakaan ISI Yogyakarta}


Dewojati Cahyaningrum pada buku DRAMA: Sejarah, teori, dan penerapannya. Beberapa teori penyutradaraan berpedoman pada buku ini. Seperti teori Lizzes Faire dan Gordon Craig yang dapat diaplikasikan pada saat proses kreatif pertunjukkan Sultan Thaha Saifuddin.

\section{E. Landasan Teori}

Penentuan teori berguna untuk pijakan awal dalam memulai sebuah proses penciptaan pertunjukan teater. Mengangkat sebuah cerita perjuangan rakyat menjadi bentuk pertunjukan teater modern berbasis teater tradisi Dul Muluk, perlu ditentukan beberapa teori untuk memperkuat gagasan dalam menciptakan karya. Dewojati menuliskan dalam buku Drama, sejarah, teori, dan penerapannya mengenai teori penyutradaraan. Pertama, teori Gordon Craig yang pada prinsipnya mengacu kepada kesatuan ide antara pemain dan sutradara. Jika teater merupakan seni, maka karya itu harus mengekspresikan kepribadian si seniman. Aktor yang dianggap baik dalam teori ini adalah aktor yang mampu mendedikasikan kerjanya terhadap ide sutradara. Kebaikan teori ini adalah hasil pementasan yang biasanya sempurna, tata tertib terjamin, teratur, dan teliti. Kelemahan atau keburukan teori ini bahwa sesutradara menjadi bisa menjadi diktator; aktor dan aktris hanya menjalan alat sutradara (Dewojati, $2012: 284$ ).

Kedua, teori Lissez Faire yang memungkinkan aktor dan aktris menjadi pencipta dalam teater. Sementara itu, tugas sutradara adalah membantu aktor dan aktris mengekspresikan dirinya dalam lakon. Dengan demikian, sutradara sebagai seorang supervisor membiarkan aktor dan aktris bebas 
mengembangkan konsep individualnya agar melaksanakan peran dengan sebaik-baiknya. Kebaikan teori ini adalah sutradara bukan lagi menjadi seorang diktator, melainkan pembantu dalam berekspresi. Aktor dan aktris dibiarkan berkembang menurut bakat dan kemampuannya masing-masing. Dengan demikian seorang sutradara memberi kesempatan timbulnya proses-proses kreatif. Kelemahan teori ini adanya resiko timbulnya kekacauan dan kekurangteraturan, dan ketidaktelitian dalam produksi pementasan. Hal ini terjadi karena tiap-tiap aktor dan aktris dibiarkan berkembang menurut kemampuannya masing-masing. Hal tersebut memungkinkan hanya aktor dan aktris yang kuat saja yang akan menonjol dan berhasil (Dewojati, 2012 : 284).

Proses penyutradaraan naskah Sultan Thaha Saifuddin akan baik jika kedua teori tersebut dikombinasikan. Teori Gordon Craig menekankan pada satu keutuhan konsep yang dipegang penuh oleh sutradara sehingga mampu mencapai pementasan yang sempurna. Sementara teori Lissez Faire akan menjadi media proses kreatif kepada aktor dan aktris untuk berekspresi berdasarkan naskah Sultan Thaha Saifuddin.

Penciptaan pertunjukan teater Sultan Thaha Saifuddin berbasis teater tradisi Dul Muluk tentu berakar pada konsep teater tradisi melayu. Pulau Sumatera sangat identik dengan kultur budaya Melayu mulai dari bagian paling ujung utara (Aceh) sampai ujung selatan (Lampung). Jambi sebagai kota asal perjuangan Sultan Thaha Saifuddin berada pada wilayah Sumatera Tengah sebelum berkembang menjadi provinsi sendiri seperti saat ini.

\section{UPT Perpustakaan ISI Yogyakarta}


Pada umumnya jenis teaternya adalah teater tradisional dengan kesamaan latar belakang rumpun budaya Melayu yang sangat dominan, meskipun akarnya tetap pada budaya etnik setempat. Rumpun budaya Melayu dapat diidentifikasi dari cara penyajian materi, baik musik yang disajikan ataupun tari dan gaya penyajiannya. Tari dan musik yang mendukung, berbasis tari dan musik Melayu, serta kelengkapannya (Achmad, 2006: 110). Bangsawan, merupakan teater tradisional yang umumnya terdapat di Pulau Sumatera dengan latar belakang pendukung yang dominan budaya Melayu. Ada beberapa nama untuk Teater Bangsawan, $\_$sering juga orang menamakan Komidi Bangsawan, Sandiwara Dardanella, Komidi Stamboel, yang merupakan teater tradisional yang telah banyak memperoleh pengaruh teknik teater Barat, hal ini dapat kita lihat pada cara pementasannya yang selalu dilakukan di atas panggung, meskipun tidak di dalam gedung (Achmad, 2006: 112).

Di Sumatera Selatan, kita temukan teater tradisional yang sejenis dengan Bangsawan, yang dinamakan: Dul Muluk, tetapi sering juga disebut: Abdul Muluk, atau Indra Bangsawan (Achmad, 2006: 112). Bentuk pertunjukan Abdul Muluk tak ubahnya sebagai teater rakyat umumnya, terutama teater rakyat yang ditopang dan didominasi oleh latar belakang budaya Melayu. Bentuk pertunjukan menggunakan campuran media ungkap terdiri dari tari, nyanyi, laku, dengan menggunakan dialog yang sering dinyanyikan (Achmad, 2006: 126).

\section{UPT Perpustakaan ISI Yogyakarta}


Pengaruh budaya melayu juga terdapat di Jambi mengingat letak goegrafis di $0,45^{\circ}$ Lintang Utara, $2,45^{\circ}$ Lintang Selatan dan antara $101,10^{\circ}-104,55^{\circ}$ Bujur Timur. Di sebelah Utara berbatasan dengan Provinsi Riau, sebelah Timur dengan Selat Berhala, sebelah Selatan berbatasan dengan Provinsi Sumatera Selatan dan sebelah Barat dengan Provinsi Sumatera Barat dan Provinsi Bengkulu. Kondisi geografis yang cukup strategis memberikan pengaruh budaya yang sangat besar bagi penduduk Jambi. Kedekatan wilayah Jambi dengan Palembang secara geografis membuat Dul Muluk jauh lebih dikenal dikalangan masyarakat.

Dul Muluk sampai saat ini merupakan salah satu teater tradisi yang dikenal di Jambi. Tetapi Dewojati (2012: 94), A. Kasim Achmad (2006: 125) menuliskan Teater Dul Muluk berasal dari Sumatera Selatan. Salah satu versi menyebutkan bahwa teater ini berasal dari syair Raja Ali Haji, sastrawan yang pernah bermukim di Riau. Bentuk pertunjukan Dul Muluk tidak berbeda sebagai teater rakyat umumnya. Bentuk pertunjukan menggunakan campuran media ungkap terdiri dari tari, nyanyi, laku, dengan menggunakan dialog yang sering dinyanyikan. Karena ungkapan dialog yang berbentuk pantun, maka cara mengungkapkan yang paling tepat adalah dinyanyikan. Unsur musik merupakan bagian yang tak terpisahkan dari lakon yang dipertunjukkan. (Achmad, 2006: 126). Pada pertunjukkan Sultan Thaha Saifuddin nanti mengedepankan basis teater tradisi Dul Muluk yaitu: menghadirkan tari, nyanyi, laku, dan musik melayu ke dalam sebuah cerita tetapi tidak lagi yang 
berbentuk pantun. Cerita Sultan Thaha Saifuddin kali ini sudah menjadi bentuk naskah yang baku dan verbal.

Kasim Achmad (2006: 128) lebih spesifik menjelaskan bahwa dalam pertunjukan teater tradisi Dul Muluk, bahasa yang digunakan adalah bahasa melayu lama (bahasa melayu tinggi). Pertunjukan dilakukan dalam bentuk arena di alam terbuka hingga terasa akrab dengan penonton. Cara menyampaikan ceritera dengan gaya “dagelan”, penuh humor dan tertawa. Setiap adegan selalu diselipkan banyolan atau dagelan karena adegan inilah yang digemari penonton.

Unsur-unsur/penting dalam teater tradisi Dul Muluk tersebut kemudian diaplikasikan ke dalam proses penyutradaraan naskah Sultan Thaha Saifuddin: Tari, musik, nyanyi bernuansa melayu menghadirkan unsur-unsur modern. Bahasa yang digunakan adalah Bahasa Indonesia mengikuti naskah dengan cara dialog menggunakan dialeg Melayu Kota Jambi yang lebih modern dan mudah dimengerti oleh masyarakat kekinian. Pertunjukan akan dilakukan di atas panggung procenium untuk memberikan jarak estetis kepada penonton sehingga menghadirkan kesadaran akan pertunjukan yang berlangsung. Terakhir yang menjadi point of interest adalah adegan komedi akan dibawakan oleh tokoh yang hadir pada setiap adegan. Cerita perjuangan yang umumnya bersifat heroik akan ditampilkan dengan kemasan komedi tetapi cara penyampaian cerita tetap terasa serius sesuai kebutuhan naskah. 


\section{F. Metode Penciptaan}

Metode adalah cara yang tersusun dan teratur untuk mencapai tujuan khususnya dalam hal ilmu pengetahuan (Daryanto, 1997: 439). Proses penciptaan penyutradaraan naskah Sultan Thaha Saifuddin memerlukan metode. Metode yang tersusun secara sistematis akan menjadi pedoman berjalannya proses penciptaan agar mencapai target yang diinginkan.

Untuk mencapai keutuhan konsep yang direncanakan, maka akan dilakukan beberapa metode yaitu:

1. Latihan Menari Zapin

Latihan menari Zapin ditujukan agar seluruh pendukung proses pertunjukan Sultan Thaha Saifuddin karya EM. Yogiswara memiliki ketubuhan Melayu. Tari Zapin terlihat mudah ketika dipandang, akan tetapi sulit untuk dilakukan apabila belum memiliki ketubuhan melayu.

2. Latihan Acrobatic

Acrobatic dilatih untuk menciptakan spektakel di beberapa adegan. Latihan ini diperuntukan untuk para pemeran tokoh prajurit, pasukan Belanda, dan pasukan Fisabilillah supaya kehadiran adegan perang dalam pertunjukan teater tradisi melayu tidak melulu digambarkan dengan silat murni.

3. Latihan Menyanyi Acapella

Latihan ini diharapkan mampu mencapai kebaruan dalam unsur musik. Aktor dapat menciptakan musik dari organ tubuh yang dimiliki 
terutama suara. Sehingga dapat memadukan bunyi alami dengan bunyi instrument yang sudah modern.

\section{Latihan Menyanyi Melayu Bersama (Koor)}

Latihan koor diharapkan mampu mengatasi satu permasalahan ruang pemanggungan yang dipilih. Tujuan lainnya agar tercapainya sebuah harmonisasi nada secara bersama-sama ketika aktor menyanyikan lagu-lagu yang telah dipersiapkan.

Setelah unsur-unsur yang diperlukan sudah dikuasai barulah mengemas pertunjukan secara utuh berdasarkan tugas dan tanggung jawab sutradara. Mengutip mengenai tugas sutradara berada pada beberapa tahapan yaitu, pertama, sutradara menterjemahkan naskah untuk menentukan gaya panggung sebagai konsep dasar produksi. Gaya ini kemudian berguna untuk membentuk panggung. Kedua, sutradara memilih dan melatih pemain. Ketiga, sutradara menjalin kerja sama dengan penata artistik. Keempat, sutradara menyatukan seluruh elemen kerja hingga akhir produksi (Yudiaryani, 2002: 344). Berdasarkan pada beberapa tahapan tersebut kemudian lebih dirincikan wilayah kerja penyutradaraan sebagai berikut:

1. Memilih pemain dan pekerja artistik.

2. Bekerja sama dengan staf artistik dan non artistik.

3. Menafsir naskah lakon dan menginformasikannya kepada seluruh pekerja (artistik dan non artistik).

4. Menafsir karakter peranan dan menginformasikannya kepada seluruh pemain (aktor-aktris).

\section{UPT Perpustakaan ISI Yogyakarta}


5. Melatih pemain agar bisa memainkan peranan berdasar tafsir yang sudah dipilih.

6. Mempersatukan seluruh kekuatan dari berbagai elemen teater sehingga menjadi sebuah pergelaran yang bagus, menarik, dan bermakna.

\section{G.Sistematika Penulisan}

Skripsi harus disusun secara sistematis untuk memudahkan penyampaian dan pemaparan konsep. Berikut adalah rencana penulisan dalam penciptaan karya seni penyutradaraan naskah Sultan Thaha Saifuddin:

BAB I merupakan pendahuluan yang terdiri dari latar belakang penciptaan, rumusan penciptaan, tujuan penciptaan, tinjauan pustaka dan tinjauan karya, landasan teori, metode penciptaan dan sistematika penulisan.

BAB II merupakan analisis naskah yang berisi paparan konsep proses penciptaan. Mulai dari biografi penulis naskah, ringkasan cerita, analisis naskah secara struktur yang menjelaskan tema, plot, latar cerita, penokohan, dan analisis naskah secara tekstur yang membahas suasana, dialog dan spektakel.

BAB III merupakan proses penciptaan yang menjelaskan penjabaran konsep penyutradaraan, proses kreatif penyutradaraan, proses latihan sampai tahap pementasan, berikut dengan konsep artistik yang meliputi tata pentas, tata cahaya, tata rias, tata busana, dan tata suara.

BAB IV merupakan kesimpulan dari proses penciptaan serta saran yang dapat diberikan setelah melakukan proses penciptaan. 